Due diligence in the process of provision of healthcare services refers, among other elements, to the application of pharmacological therapy at a time which offers the greatest chance for a successful outcome of treatment, i.e. for achieving the optimum expected effect understood as an improvement in the patient's health, reduction of health risks or elimination of the disease. However, due diligence may also refer to actions aimed at ensuring that neither the patient nor the healthcare payer is required to incur unreasonable costs in the process of treatment. The validity of that statement stems not only from normative acts but also from ethical standards laid down in the Medical Code of Ethics (Article 57 section 2). It often happens that the provision of optimal treatment calls for deviations from the formal provisions included in Summary Product Characteristics (SPCs), and the application of drugs that are bioequivalent to reference drugs, which translates into a significant reduction of costs. The present study addresses the problem of acceptability of a specific form of drug substitution consisting in the replacement of a reference drug with a generic drug. Also explored are legal aspects associated with the possibility of therapy based on "off-label use".

The study reviews normative acts existing in the Polish and EU legislation. It also provides a clear definition of orphan drug, which has made it possible to make a distinction and investigate mutual relations between the concepts of brand-name (reference) drug, orphan drug and generic drug.

Key words: brand-name drug, orphan drug, generic drug, bioequivalence of medicinal products, "off-label use".

Contemp Oncol (Pozn) 2013; 17 (6): 477-483 DOI: $10.5114 /$ wo.2013.38909

\section{Brand-name drug, generic drug, orphan drug. Pharmacological therapy with biosimilar drugs - provision of due diligence in the treatment process}

\author{
Justyna Zajdel'1, Radosław Zajdel ${ }^{2}$
}

${ }^{1}$ Department of Medical Law, Medical University of Lodz, Poland

${ }^{2}$ Medical University of Lodz, Poland

\section{Introduction}

Due diligence in the process of provision of healthcare services refers, among other elements, to the application of pharmacological therapy at a time which offers the greatest chance for a successful outcome of treatment, i.e. for achieving the optimum expected effect understood as an improvement in the patient's health, reduction of health risks or elimination of the disease. However, due diligence may also refer to actions aimed at ensuring that neither the patient nor the healthcare payer is required to incur unreasonable costs in the process of treatment. The validity of that statement stems not only from normative acts but also from ethical standards laid down in the Medical Code of Ethics (Article 57 section 2) [1], a violation of which may be subject to sanctions according to the rules of professional liability of medical practitioners. It often happens that the provision of optimal treatment calls for deviations from the formal provisions included in Summary Product Characteristics (SPCS), and the application of drugs that are bioequivalent to reference drugs, which translates into a significant reduction of costs. The present study addresses the problem of acceptability of a specific form of drug substitution consisting in the replacement of a reference drug with a generic drug. Also explored are legal aspects associated with the possibility of therapy based on "off-label use".

The study will discuss problems caused by approval limitations that are in place for the generic form of imatinib, resulting from the "legal barrier" of the indication held by the reference drug called Glivec, i.e. "adult patients with newly diagnosed Philadelphia chromosome (bcr-abl) positive $(\mathrm{Ph}+)$ chronic myeloid leukaemia for whom bone marrow transplantation is not considered as the first line of treatment". It needs to be noted that no generic versions of the medicinal product Glivec (such as Telux) may be approved for the indication defined above in spite of the availability of up-to-date and scientifically verified medical knowledge, demonstration of full bioavailability and therapeutic efficacy based on many years of clinical experience. The current status of the drug is related to specific legal requirements concerning the treatment of the above indication rather than any objective medical or economic factors.

\section{Material and methods}

The study reviews normative acts existing in the Polish and EU legislation. It also provides a clear definition of orphan drug, which has made it possible to make a distinction and investigate mutual relations between the concepts of brand-name (reference) drug, orphan drug and generic drug. 


\section{Results}

Analyzing issues related to the introduction of pharmacological therapy that deviates from the drug's SPC (hereinafter "off-label use"), a distinction must be drawn between the use of medicinal products for an unapproved indication and their use in an unapproved dosage regimen, applying an unapproved route of administration or an unapproved dose size - or using a medicinal product in an age group that is not listed in its SPC. Particular attention should be given to cases in which a medicinal product is used in compliance with approved indications, however in an age group that is not listed in the approved SPC of the drug.

\section{Off-label use, or treatment outside the Summary Product Characteristics as a form of due diligence in the diagnostics and therapeutic process}

Under Article 4 of the Act on the Professions of Physician and Dentist (hereinafter APPD) [2], the fundamental duty of every physician is to diagnose and treat diseases with the application of due diligence. The application of due diligence in the broadly understood process of medical treatment does not encompass solely the introduction of optimal therapeutic management according to the current state of medical knowledge, but also the application of selected medicinal products in compliance with their approved uses specified in SPC, and initiation of treatment going beyond the limits specified in the SPC in all circumstances in which the welfare of the patient is at stake. One example is the introduction and continuation of therapy in the paediatric population in situations where many medicinal products approved for the treatment of adult patients do not have equivalent approval for the treatment of children. Much more uncommon are opposite situations in which a medicinal product is approved for use in the paediatric population but not in the adult population. If the current state of medical knowledge and the properties of a medicinal product suggest that it may be successfully used in adult patients, the presence of medical factors validating the use of the drug in a specific case of an adult patient fully justifies the initiation of therapy despite the fact that the drug only has a formal approval for use in the paediatric population. The scenario, which is relatively rare, will be explored below on the example of two medicinal products: Glivec (imatinib) and Telux (imatinib). The former represents the brandname drug approved for the treatment of newly diagnosed myeloid leukaemia in adult patients. The latter is a generic drug which has proven equivalent efficacy in the treatment of the disease, and at the same time makes it possible to reduce the cost of therapy by at least $25 \%$ according to the Drug Reimbursement Act. The SPC of Telux specifies its target group as the paediatric population, while restricting treatment in the adult population.

Prior to embarking on a detailed discussion of the acceptability of use of medicinal products beyond SPC provisions, it is apt to provide clear definitions of medicinal product and healthcare services, and clarify selected aspects associated with the term "off-label use".
Definition. Under Article 2 section 32 of the Act on Pharmaceutical Law (hereinafter APL), "a medicinal product shall mean any substance or combination of substances presented as able to prevent or treat disease in human beings or animals, or administered with a view to making a medical diagnosis or to restoring, correcting, or modifying physiological functions of an organism through pharmacological, immunological or metabolic action" [3].

Definition. Under Article 2 section 1 item 10 of the Act on Medical Activity [4], healthcare services refer to all "actions undertaken with a view to maintaining, saving, restoring or improving patients' health, and other medical activities that result from the process of treatment or separate regulations governing their performance". One of the types of healthcare services is pharmacological therapy which is the foundation of treatment in non-surgical medicine.

Reference literature on the topic of using medicinal products beyond their strictly approved indications also defines "off-label use" as using a drug contrary to approved product information, and introducing treatment in a manner that does not comply with the drug's patient information leaflet (PIL) [5].

Reference literature [6] defines four scenarios in which drugs are not used in compliance with their strictly approved indications. These include:

- using a medicinal product in a manner or via a route of administration that is not listed in the product's SPC;

- using a medicinal product in compliance with the approved indication in patients for whom no dosage regimen has been established;

- using a medicinal product in an indication that is not listed in the product's SPC but is validated by reliable data demonstrating its safety and efficacy;

- using a medicinal product in a new indication that has not been validated, on the basis of scientific evidence giving grounds to expect that it will be safe and effective.

The author believes that it is vital to draw a clear distinction between "off-label" use of medicinal products which refers to drug use beyond its strictly approved indication (narrow interpretation of "off-label use") and the remaining cases (wide interpretation of "off-label use") [7]. In its wide interpretation, "off-label use" should be understood as referring to:

- using a medicinal product via a different route of administration,

- using a medicinal product in the approved indication in a group of patients for whom no dosage regimen is defined in the SPC,

- introducing treatment in an age group which is not listed in the SPC.

The wide interpretation outlined above seems quite uncontroversial, however using a drug in a different indication than the approved indication defined in the SPC (narrow interpretation of "off-label use") is especially problematic. It must be stressed at this point that regardless of the fact whether "off-label use" is understood in the wider or narrower sense, in the present study it is identified with any uses other than those specified in the marketing authorization, i.e. in a manner that has not been approved by 
the authority that is formally in charge of medicinal product approval.

As already mentioned above, any use of the medicinal product that is contrary to the SPC is a deviation from the rule - just like introduction of therapy based on "off-label use" is, in many cases, consistent with the principle of due diligence in the treatment process and thus complies with the current state of medical knowledge [8]. In addition to generally acknowledged and literature-reported cases of "off-label" therapy discussed above, using medicinal products in indications that are not defined in their SPCs seems justified subject to the fulfilment of one of the conditions enumerated below [9]:

1. It is necessary to save the life or health of a patient, or protect a patient from a potential exacerbation of health risks.

2. All available medicinal products approved for a particular indication have already been used in the treatment process.

3. Prior therapy has been ineffective.

4. The outcome of prior treatment is unsatisfactory.

An analysis of the legitimacy of using medicinal products beyond the SPC is linked to the question of how one should judge a physician who decides to use medicinal products on an "off-label" basis. The answer to the question is far from unambiguous. Under Article 21 of the APPD, a "therapeutic experiment consists of the introduction by the physician of new or only partially proven diagnostic, therapeutic or preventive methods in order to achieve direct benefit to the health of the patients, and it can be carried out when hitherto applied methods were ineffective or their effectiveness was insufficient" [2]. If a medicinal product is not approved for use in a strictly defined indication, using it must be interpreted in categories similar to conducting a therapeutic experiment. It results from the fact that clinical trials carried out in the context of the drug approval process refer to strictly defined indications, which narrows down the possibility of using the drug in other indications, i.e. those that are not covered by the trials. A completely different situation applies to the acceptability of use of a medicinal product in conformity with approved indications listed in the SPC but in an age group that is not included in the SPC. This is especially important when a medicinal product has been approved for use in the paediatric population but has no formal approval for use in the treatment of adult patients.

If a physician decides to introduce a medicinal product in compliance with the approved indication in a group of adult patients which is not specified in the SPC, the decision must be identified as a measure conforming to the current state of medical knowledge when potential therapeutic benefits significantly outweigh the risk of adverse effects to the patient's health. Therefore, the action taken by the physician should not be regarded as consistent with the concept of therapeutic experiment within the meaning of Article 21 section 2 of the APPD, but rather with the initiation of therapy in line with the duty of due diligence which every physician is obliged to perform under Article 4 of the APPD [2]. It must also be noted that medical practitioners have a duty to select an appropriate treatment not only under legal (normative) acts in place, but also in accordance with the Medical Code of Ethics [1]. Failure to comply with the provisions of the Code may give rise to sanctions imposed by the Medical Tribunal according to the rules of professional liability. The Medical Code of Ethics obliges physicians to introduce a therapy which does not put patients to excessive costs, where the principle of rational management of treatment costs must also be applied to the healthcare institution and the payer. An example is the possibility of using therapy based on the generic drug Telux in all patients suffering from chronic myeloid leukaemia, rather than just in the paediatric population. Under the Reimbursement Act, treatment with the drug might be at least 25\% cheaper than therapy based on Glivec. The extension of population-related indications of Telux beyond the SPC must be considered on an individual basis depending on the situation.

As previously mentioned, the introduction of pharmacological therapy in an approved indication in an age group which is not listed in the SPC constitutes an acceptable practice from the legal perspective as long as the use of a given medicinal product complies with the current state of medical knowledge. The action, however, may not be identified with a therapeutic experiment due to the fact that the medicinal product is approved for use in the indication concerned, and the approval process is based on the same clinical trials which were a basis for the registration of other medicinal products dedicated to the treatment of a given condition in all age groups.

Importantly, in order to use of a medicinal product in an age group that is not listed in the SPC, certain formal requirements must be satisfied, as laid down in the Statement of the Ministry of Health on the financing of drug therapies which are not covered by approval indications from public funds [10]. "If a drug is to be used beyond its approved indications, the healthcare service provider is obliged to follow the procedure defined below:

1. Obtain an approval from the provincial or national consultant in the respective area of medicine stating that the proposed use of the medicinal product "complies with the state of current medical knowledge".

2. Prior to introducing therapy with a drug for indications which are not listed in the drug's SPC for a particular condition check whether there are any other clinically proven methods of treatment of the condition.

3. Prior to introducing "off-label" therapy obtain the patient's written informed consent.

4. Monitor the patient's health status" [11].

\section{Example}

If a medicinal product, e.g. Telux, has been approved for use based on the same clinical studies as Glivec, but it is intended for the treatment of paediatric patients (as specified in the SPC), therapy based on Telux introduced in the approved indication in the adult population is an acceptable practice from the legal perspective. Such course of action may be deemed legitimate based on the current state of medical knowledge, scientifically verified validation of the practice, and determination that potential benefits of 
the pharmacological therapy clearly outweigh the risk of adverse effects to the patient's health. One of the key factors determining the acceptability of Telux treatment and legitimizing its use also in the extended population rather than the approved paediatric population is its bioequivalence with Glivec.

\section{Bioequivalence of medicinal products}

The first section of the present study addresses the is sues of acceptability and legitimacy of use of medicinal products beyond specifications included in the SPC. Aside from the set of formal requirements that must be satisfied to ensure legal safety of the decision, the acceptability of pharmacological therapy based on "off-label use" depends on the demonstration of bioequivalence of medicinal products. If medicinal products are recognized as bioequivalent, it is possible to substitute the reference (brand-name) drug with a generic product which has the same approved therapeutic indications but has not been approved for use in all age groups.

Definition! Under Article 10(2b) of Directive 2001/83/EC of the European Parliament and of the Council [12] generic medicinal product is "a medicinal product which has the same qualitative and quantitative composition in active substances and the same pharmaceutical form as the reference medicinal product, and whose bioequivalence with the reference medicinal product has been demonstrated by appropriate bioavailability studies (...)".

A generic drug can be approved as an equivalent of a reference (brand-name) drug subject to the submission of positive results of bioequivalence studies to the Office for Registration. Reference literature lists several ways of demonstrating bioequivalence (ranked below from the most "convincing") [13]:

- demonstration of identical action of the drugs, as measured by clinical benefit, in patients (clinical efficacy studies);

- demonstration of identical pharmacokinetics (i.e. blood concentration profiles) of the drugs in a group of volunteers (bioequivalence studies);

- demonstration of identical physical and chemical properties determining active substance release from the drug dosage form (in vitro release studies).

The basic requirements regarding the methodology of studies investigating biological equivalence are laid down in guidelines published by the European Medicines Agency (EMA) [14].

Criteria applied for the assessment of bioequivalence by the Polish Office for Registration of Medicinal Products, Medical Devices and Biocidal Products include factors which may potentially affect the biological availability of a medicinal product and which are related to the characteristics of active substances, the pharmaceutical form of the medicinal product concerned, its excipients, and intra- and inter-individual variation of pharmacokinetic parameters [15].

Bioequivalence studies of generic products must be conducted in compliance with Good Clinical Practice requirements and legal regulations governing clinical trials. Conditions applicable to conducting clinical trials of me- dicinal products are specified in chapter $2 a$ of the Act on Pharmaceutical Law [3].

In accordance with Article 37b section 1 of the APL "clinical trials, including the bioavailability and bioequivalence trials, shall be planned and conducted and the report on the clinical trials shall be presented in accordance with Good Clinical Practice" [3].

Definition. Under Article 2 section 2 of the APL [3], "a clinical trial shall mean each trial conducted in humans to discover or confirm the clinical, pharmacological, including pharmacodynamic, effects of action of one or more investigational medicinal products, or to identify the adverse reactions to one or more investigational medicinal products, or to monitor absorption, distribution, metabolism and excretion of one or more investigational medicinal products, taking into consideration their safety and efficacy". From the perspective of the law, a clinical trial is a type of research experiment undertaken in order to expand medical knowledge.

Definition. In line with Article 2 section 6 of the APL [3] "Good Clinical Practice shall mean a set of internationally recognised ethical and scientific quality requirements for the conduct of clinical trials, providing assurance that the rights, safety and well being of trial subjects are protected and that the results of the clinical trials are credible". Detailed aspects related to Good Clinical Practice are provided for in the Regulation of the Minister of Health on Good Clinical Practice [16].

For generic products it is not necessary to submit to drug approval authorities complete results of preclinical and clinical studies that have been carried out with regard to the reference (brand-name) product. Aside from the ethical aspect (limitation of patient enrolment in identical clinical trials), reducing clinical trials is also justified from the viewpoint of cost-effectiveness (cost reduction) and time constraints (maximum reduction of time required for obtaining the marketing authorization for a medicinal product). For generic drugs evidence must be provided that a particular generic medicinal product is equivalent to its reference (brand-name) drug, i.e. the active substance contained in the generic product does not differ in structure and physicochemical properties from the active substance used in the innovative drug. Also, it must be demonstrated that both medicinal products induce the same therapeutic effect.

It must be noted that two medicinal products are said to be bioequivalent if they are pharmaceutical equivalents or alternative pharmaceutical products, and if their bioavailabilities after administration in the same molar dose are similar to such a degree that their efficacy and safety can be expected to be essentially the same.

Directive 2004/27/EC of the European Parliament and of the Council [17] defines generic medicinal product as a medicinal product which has the same qualitative and quantitative composition in active substances and the same pharmaceutical form as the reference medicinal product, and whose bioequivalence with the reference medicinal product has been demonstrated by appropriate bioavailability studies. 
Using a generic medicinal product beyond strictly defined provisions included in the SPC complies with the current legal regulations, especially if "off-label use" consists basically of the extension of approved age limits, whereas all assumptions related to the product's therapeutic indications are followed. Referring to the example of Telux (imatinib in the form of imatinib mesylate, equivalent to Glivec), introducing therapy based on the drug in adult patients with newly diagnosed chronic myeloid leukaemia cannot be recognized as an experimental measure because bioequivalence can be demonstrated with the reference product which is formally approved in the required indication for all therapeutic groups.

A vital element of the discussion on the use of bioequivalent generic products instead of reference medicinal products is the economic aspect of treatment. It sometimes happens that the optimal therapeutic regimen, which carries the greatest chance for a positive outcome, cannot be given to the patient because of economic considerations. Difficult financial position of the healthcare provider, the payer or even the entire state, however, should not play the decisive role for the introduction of available dedicated therapy. Under Article 6 section 1 of the Act on the Rights of Patient and the Ombudsman of the Patient [18], "every patient has the right to receive healthcare services consistent with the current state of medical knowledge". It must be stressed that the current state of medical knowledge accepts the use of a bioequivalent medicinal product instead of the reference drug, which has no effect on the quality of treatment and clinical effect.

If introducing treatment based on a reference drug is not possible or it is difficult due to economic reasons, legal regulations state that the patient must be given pharmacological treatment using a bioequivalent medicinal product which can be used from the perspective of the financial standing of the healthcare provider. Any decision not to initiate therapy with a bioequivalent medicinal product would be a breach of the patient's right to receive a healthcare service that is consistent with the current state of medical knowledge.

\section{Orphan medicinal products}

The section below outlines the concept of "orphan medicinal product". Understanding the concept may be important for the process of treatment of chronic myeloid leukaemia in adult patients because in 2006 the active substance called nilotinib (Tasigna) was granted the status of orphan drug, which prevents the treatment of this group of patients with generic products based on imatinib. The restriction, however, holds merely on a formal basis (to ensure compliance with the regulations in place) rather than being a result of objectively (i.e. clinically) demonstrated inferior efficacy of generic drugs.

The term "orphan drug" was first used in 1983 to describe the therapy recommended to patients suffering from rare medical conditions. Also in 1983, the first legal regulation applicable to orphan drugs was passed in the United States [19]. The American "Orphan Drug Act” was intended to create favourable conditions for conducting research and developing drugs used in the treatment of rare diseases. Similar regulations on orphan drugs were enacted in Singapore in 1991 [28], in Japan in 1993 and in Australia in 1998 [20].

As mentioned previously, the issue of orphan drugs refers to the treatment of rare medical conditions which are understood in Europe as diseases with a prevalence not exceeding 5 cases per 100,000 population [25]. In other countries, a disease is considered rare if it affects fewer than 200,000 patients annually, which corresponds to 7.5/10,000 population (USA); fewer than 50,000 patients annually, which is equivalent to 4/10,000 population (Japan); fewer than 2,000 patients annually, which corresponds to 1.1/10,000 population (Australia).

In Poland, a dedicated team responsible for rare diseases was established under the Regulation issued by the Minister of Health in 2008 [27]. One of the tasks of the team is to "cooperate with all groups and agencies having an interest in the improvement of care and treatment of rare diseases including medical societies, associations of patients, non-governmental organizations conducting health protection activities, and manufacturers or suppliers of orphan medicinal products which are used in the treatment of rare diseases" ( $\S 6$ section 10 of the Regulation).

In the framework of the EU law, the issue of orphan drugs was addressed on 16 December 1999 by passing Regulation (EC) No. 141/2000 of the European Parliament and of the Council on orphan medicinal products (hereinafter Regulation) [21]. In April 2000, under the auspices of the European Medicines Evaluation Agency (EMEA), a special body - Committee for Orphan Medicinal Products (COMP) - was established. Also, Commission Regulation (EC) No. $847 / 2000$ laying down the provisions for implementation of the criteria for designation of a medicinal product as an orphan medicinal product and definitions of the concepts "similar medicinal product" and "clinical superiority" was adopted [23]. The issue of orphan medicinal products has also been repeatedly considered by the European General Court, e.g. in judgements passed in cases T-264/07 CSL Behring or T-74/08 Now Pharm [26].

The aim of Regulation (EC) No. 141/2000 was to establish a transparent Community procedure for the designation of medicinal products as orphan medicinal products, and to create incentives for research, development and marketing of designated orphan medicinal products. A key benefit resulting from the orphan drug status is the fact that with regard to orphan drugs Member States are obliged, for a period of 10 years, not to grant a marketing authorization or accept an application to extend an existing marketing authorization for a similar medicinal product with the same therapeutic indication. It must be stressed that the period of "protection" of orphan drugs defined in Community legislation is extraordinarily long. For comparison, in the USA the period is seven years.

Designation of a medicinal product as an orphan medicinal product is dependent on the simultaneous satisfaction of the requirement set out in item 1 below, and one of the conditions listed in item 2: 
1. “(...) there exists no satisfactory method of diagnosis, prevention or treatment of the condition in question that has been authorised in the Community or, if such method exists, that the medicinal product will be of significant benefit to those affected by that condition" [21]. "Significant benefit" should be demonstrated by comparing the medicinal product for which the orphan designation is sought with drugs or therapeutic methods that are already established on the market [22].

2. A medicinal product shall be designated as an orphan medicinal product if its sponsor can establish:

a) "(...) that it is intended for the diagnosis, prevention or treatment of a life-threatening or chronically debilitating condition affecting not more than five in 10 thousand persons in the Community when the application is made" [21], or

b) "(...) that it is intended for the diagnosis, prevention or treatment of a life-threatening, seriously debilitating or serious and chronic condition in the Community and that without incentives it is unlikely that the marketing of the medicinal product in the Community would generate sufficient return to justify the necessary investment" [21]. Incentives should be understood as public aid (e.g. state subsidies) contributed to clinical trials, exemption from approval-related fees, etc.

Obtaining the orphan drug status carries a range of important benefits such as the privilege of market exclusivity. Crucially, "similar medicinal products" (as defined below) may not be granted approval for the therapeutic indication specified in the orphan drug's SPC for a period of 10 years from the date of granting the marketing authorization to the orphan drug. The mandatory 10-year period may be reduced to six years if at the end of the fifth year it is demonstrated that the criteria required for maintaining the orphan drug status are no longer met. Exceptions from this generally valid rule include situations where the holder of the marketing authorisation for the original orphan medicinal product has given consent to granting a marketing authorization to a similar drug in the indication reserved for the orphan drug; it is not possible to supply sufficient quantities of the orphan medicinal product, or it can be established that the medicinal product similar to the orphan medicinal product already authorized is safer, more effective or otherwise clinically superior to the orphan drug. Since the issue is quite critical, the section below presents the definition of "critical superiority" which is a basis for the potential granting of marketing authorization to a similar product in the indication initially reserved for the orphan drug.

Definition. According to Art. 3(3b) of the Commission Regulation (EC) No. 847/2000 [23], a similar medicinal product means "(...) a medicinal product containing a similar active substance of substances as contained in a currently authorised orphan medicinal product, and which is intended for the same therapeutic indication" [23].

Definition. Under Article 3(3d)(1-3) of the Commission Regulation (EC) No. 847/2000 [23], "clinically superior means that a medicinal product is shown to provide a significant therapeutic or diagnostic advantage over and above that provided by an authorized orphan medicinal product in one or more of the following ways: greater efficacy than an authorised orphan medicinal product (as assessed by effect on a clinically meaningful endpoint in adequate and well controlled clinical trials), (...) greater safety in a substantial portion of the target population(s) (...) in exceptional cases, where neither greater safety nor greater efficacy has been shown, a demonstration that the medicinal product otherwise makes a major contribution to diagnosis or to patient care".

Designating a medicinal product as an orphan drug leads to significant limitations with respect to the approval of similar medicinal products in the same therapeutic indications as those specified in the SPC of orphan medicinal products. What this means is that no generic drug may be approved during the validity period of the orphan drug status. It needs to be emphasized, though, that the special status of orphan drugs is only formal, arising from legal regulations, rather than substantive, i.e. stemming from medical considerations. As the above discussion shows, formal provisions concerning the approval of generic drugs sometimes differ from the approved indications of reference (brand-name) drugs, which is not dictated by the current state of medical knowledge or differences in the methodology of clinical trials, but formal protection granted as part of the orphan drug status.

\section{Example}

The situation outlined above, resulting solely from legal limitations, seems archaic not only from the perspective of medicine and the due diligence principle, but also from the viewpoint of the economic interest of patients and the payer (the state). In the current circumstances physicians are unable to prescribe Telux (imatinib), which is as effective as Glivec or Tasigna (with identical efficacy confirmed on the basis of Evidence Based Medicine that must be followed to ensure compliance with the Act on the Professions of Physician and Dentist), yet cheaper. Instead, physicians are forced by purely formal procedures to prescribe a more expensive drug. The situation is even less understandable if one considers the fact that Glivec, recommended for the first year of treatment of patients with newly diagnosed chronic myeloid leukaemia, does not enjoy the orphan drug status and is no longer covered by patent protection, whereas there are several generic drugs (Telux included) that are at least $25 \%$ cheaper to use than Glivec. Only if no improvement in the patients' condition is seen after one year, they are switched to the orphan drug - Tasigna.

In the light of arguments presented above, the example shows clearly that there is a medically and economically justifiable, and legally compliant solution. Following demonstration of justified medical reasons, Telux treatment could be introduced on an "off-label" basis not only in patient groups that are mentioned in the SPC of Telux but also in other patient populations, adult patients included. 


\section{Discussion}

Using a generic medicinal product which is bioequivalent to the reference product is a practice that complies with the current legal regulations and, at the same time, conforms to the due diligence principle that must be followed in the treatment process. This is especially important in situations where generic drugs offer a chance to decrease the costs of therapy and thus, in many cases, make it possible to initiate treatment in the optimal time frame for the patient. Reduction of the costs of therapy is conducive to the implementation of the healthcare provider's tasks and also conforms to the provisions of the Reimbursement Act [24] which seeks to optimize costs of medical treatment. Although the substitution of the reference product with a generic product gives rise to no doubts in the light of the current state of medical knowledge, formal statements included in the SPCS of both medicinal products are frequently not identical. This fact, however, does not in any way rule out the possibility of using a generic product (e.g. Telux) in an extended patient population because the generic and reference products have an identical scope of approval in terms of therapeutic indications, differing only with respect to age groups in which therapy can be applied. Considering the bioequivalence of both products, using a generic product in the approved indication but in a different age group than that defined in the SPC is a practice which cannot be classified as a therapeutic experiment. The decision, though fully acceptable and safe, requires the satisfaction of certain formal conditions such as obtaining the patient's informed consent to the introduction of therapy based on "off-label use".

The authors declare no conflict of interests.

\section{References}

1. Kodeks etyki lekarskiej, t.j. z dnia 2 stycznia 2004 r., zawierający zmiany uchwalone w dniu 20 września 2003 r. przez Nadzwyczajny VII Krajowy Zjazd Lekarzy. Dokument dostępny na: www.nil. org.pl

2. Ustawa z dnia 5 grudnia 1996 r. o zawodach lekarza i lekarza dentysty, t.j. DzU 2011 r. Nr 277 poz. 1634.

3. Ustawa z 6 września 2001 r. Prawo farmaceutyczne, t.j. DzU 2008 r. $\mathrm{Nr} 45$ poz. 271.

4. Ustawa z 15 kwietnia 2011 r. o działalności leczniczej, t.j. DzU 2011 r. $\mathrm{Nr} 112$ poz. 654 ze zm.

5. Kapko M. Komentarz do art. 45 Ustawy o zawodach lekarza i lekarza dentysty. W: Ustawa o zawodach lekarza i lekarza dentysty. Komentarz. Zielińska E (red.). ABC Wolters Kluwer, Warszawa 2008.

6. Masełbas W, Członkowski A. Stosowanie produktów leczniczych poza wskazaniami rejestracyjnymi. Przew Lek 2008; 3: 81-7.

7. Zajdel J. Stosowanie „produktów leczniczych „off label use” w populacji pediatrycznej - działanie na granicy ryzyka czy dołożenie należytej staranności? Przegl Lek 2011; 68: 33-9.

8. Zajdel J. Moc prawna standardów medycznych i wytycznych praktyki klinicznej. Med Prakt 2010; 5: 119-24.

9. Dunne J. The European Regulation on medicines for paediatric use. Paediatr Respir Rev 2007; 8: 177.

10. Stanowisko Ministerstwa Zdrowia dotyczace finansowania ze środków publicznych terapii lekami poza wskazaniami rejestracyj- nymi. Pismo nr MZ-PLO-460-3361-15/SS/06 z dnia 20 listopada 2006 roku.

11. Szersze informacje dostępne na stronie http://nfz-bydgoszcz.pl/ contents/content/44/80.

12. Dyrektywa Parlamentu Europejskiego i Rady nr 2001/83/WE z 6.11.2001 roku, OJ U L 311 z 28.11.2001 r. ze zm.

13. Sznitowska M. Sposoby oceny jakości leków generycznych - od badania uwalniania do badania biorównoważności. Choroby Serca i Naczyń 2011; 8: 209-14.

14. "Note for guidance on the investigation of bioavailability and bioequivalence" CPMP/EWP/QWP/1401/98. Rev. 1. Dokument dostępny na stronie www.ema.europa.eu.

15. Komunikat Prezesa Urzędu Rejestracji Produktów Leczniczych, Wyrobów Medycznych i Produktów Biobójczych z 3.08.2010 roku w sprawie biorównoważności produktów odpowiedników referencyjnych produktów leczniczych. Komunikat dostępny na stronie www.urpl.gov.pl.

16. Rozporządzenie Ministra Zdrowia z dnia 2 maja 2012 r. w sprawie Dobrej Praktyki Klinicznej, DzU 2012 r. poz. 489.

17. Dyrektywa Parlamentu Europejskiego i Rady nr 2004/27/WE z 31.03.2004 r., zmieniająca Dyrektywę nr 2001/83/WE, OJ L 136/43 $z 30.04 .2004$ r.

18. Ustawa z dnia 6 listopada 2008 r. o prawach pacjenta i Rzeczniku Praw Pacjenta, t.j. DzU 2012 r. poz. 159.

19. Zimmermann A, Zimmermann R. Sieroce produkty lecznicze. Farm Pol 2009; 65: 15-8.

20. Meekings KN, Williams CS, Arrowsmith JE. Orphan drug development: an economically viable strategy for biopharma R\&D. Drug Discov Today 2012; 17: 660-4.

21. Welk B, Szeligowski M, Stańczak A. Prawne aspekty leków sierocych na świecie. Farm Pol 2005; 61: 1045-9.

22. Mitsumoto J, Dorsey ER, Beck CA, Kieburtz K, Griggs RC. Pivotal studies of orphan drugs approved for neurological diseases. Ann Neurol 2009; 66: 184-90.

23. Zarządzenie Ministra Zdrowia z dnia 21 lipca 2008 roku w sprawie powołania Zespołu do spraw Chorób Rzadkich, DzU 2008 r. Nr 8 poz. 36 ze zm.

24. Rozporządzenie Parlamentu Europejskiego i Rady nr 141/2000 w sprawie sierocych produktów leczniczych z 16.12.1999 r., OJ L18 z 22.01.2000 r.

25. Rozporządzenia Komisji nr 847/2000/WE z 27.04.2000 r., ustanawiające przepisy w celu spełnienia kryteriów oznaczania produktów leczniczych jako sierocych produktów leczniczych oraz definicje pojęć „podobnego produktu leczniczego” i „wyższości klinicznej", OJ L 103/5 z 28.04.2000 r.

26. CSL Behring przeciwko Komisji i EAL. WYROK SADU (piąta izba) z dnia 9 września 2010 r. w sprawie T-264/07. Dostępny na: http:// eur-lex.europa.eu/LexUriServ/LexUriServ.do?uri=CELEX:62007TJ0264:PL:PDF.

27. Now Pharm przeciwko Komisji. Wyrok Sądu z dnia 9 września 2010 r. (Sprawa T-74/08). Dostępny na: http://eur-lex.europa.eu/ LexUriServ/LexUriServ.do?uri=OJ:C:2010:288:0033:0034:PL:PDF.

28. Maj M, Zieliński W. Terapia i Leki 2003; 5/6: 26-9.

29. Ustawa z dnia 12 maja 2011 r. o refundacji leków, środków spożywczych specjalnego przeznaczenia żywieniowego oraz wyrobów medycznych, DzU 2011 r. Nr 122 poz. 696 ze zm.

\section{Address for correspondence}

\section{Radosław Zajdel}

Medical University of Lodz

Haller Square 1

90-647 Lodz, Poland

e-mail: zajdel@toya.net.pl

Submitted: 12.09 .2013

Accepted: $\quad 15.11 .2013$ 